NBER WORKING PAPER SERIES

\title{
EXTERNAL JOB CHURNING AND INTERNAL JOB FLEXIBILITY
}

\author{
Peter Cappelli \\ David Neumark \\ Working Paper 8111 \\ http://www.nber.org/papers/w8111 \\ NATIONAL BUREAU OF ECONOMIC RESEARCH \\ 1050 Massachusetts Avenue \\ Cambridge, MA 02138 \\ February 2001
}

The Wharton School of the University of Pennsylvania, and Department of Economics at Michigan State University. Both authors are affiliated with the NBER, and Neumark is a Visiting Fellow at the Public Policy Institute of California. The authors thank William H. Carter for careful research assistance, and Arne Reznek and colleagues at the Center for Economic Statistics of the U.S. Bureau of the Census for their help with data issues. This research is part of a program of studies using the National Employer Surveys that is conducted by the National Center on Post-Secondary Improvement and funded by a grant from the U.S. Department of Education's Office of Educational Research and Improvement. Any opinions expressed in this paper are those of the authors alone and do not necessarily reflect any position of the Public Policy Institute of California. The views expressed herein are those of the authors and not necessarily those of the National Bureau of Economic Research.

(C) 2001 by Peter Cappelli and David Neumark. All rights reserved. Short sections of text, not to exceed two paragraphs, may be quoted without explicit permission provided that full credit, including $(\mathrm{C}$ notice, is given to the source. 
External Job Churning and Internal Job Flexibility

Peter Cappelli and David Neumark

NBER Working Paper No. 8111

February 2001

JEL No. J63, J50

\begin{abstract}
$\underline{\text { ABSTRACT }}$
Concern about job instability and insecurity has a long history and has generated a considerable body of research across the social sciences, most recently focused on whether job stability and security have declined. Internally flexible systems for organizing work, sometimes called "functionally flexible" systems, have been proposed as arrangements that can reduce job instability and insecurity by reducing the need for firms to rely on job cuts or contingent work to be able to respond to changes in their environments. Related arguments have been made with regard to contingent work - that it allows firms to adjust labor while "buffering" their core of permanent workers from instability. We examine these arguments using three measures of instability and insecurity - voluntary and involuntary turnover and the use of contingent work - drawn from a national probability sample of establishments. We find evidence that internally flexible work systems are associated with reduced voluntary and involuntary turnover in manufacturing. But in the rest of the economy and indeed overall, they tend to be positively associated with all three measures. Further, the use of contingent work is, in fact, positively related to involuntary turnover even in manufacturing. The evidence therefore suggests that on net employers seeking flexibility in labor tend to use flexible work practices, contingent work, and turnover as complements, while only in manufacturing is there some evidence of substitutability between internal job flexibility and external job churning.
\end{abstract}

\section{Peter Cappelli}

Department of Management

The Wharton School

University of Pennsylvania

Philadelphia, PA 19104

and NBER
David Neumark

Department of Economics

Michigan State University

East Lansing, MI 48824,

Public Policy Institute of California

500 Washington St.

San Francisco, CA 94111

and NBER 


\section{Introduction}

The issue of job loss and its causes has been a central concern of social scientists studying labor markets. Psychologists have been particularly interested in voluntary turnover-the individual's decision to quit a job-using the employee as the unit of analysis. Indeed, the term "turnover" typically means voluntary quits in most of the psychology-based studies (see Hom and Griffith 1995 for a review). Economists, in contrast, have arguably been more concerned about involuntary turnover-the employer's decision to terminate the relationship through layoffs in particular-focusing to some extent on labor markets as the unit of analysis (Baily 1974; Feldstein 1976; Medoff 1979), and on the incentives posed by the unemployment insurance system (Topel 1984).

The recent scholarly and business practice literature has paid particular attention to job loss and insecurity, no doubt mirroring developments in the economy as a whole. The corporate restructuring and downsizing announcements in the 1980s and 1990s focused attention on the very basic question as to whether job insecurity (the risk of losing a job and the related consequences) and job instability (the average tenure of a job) had changed. While the earlier evidence was divergent, more recent evidence generally points to declines in job stability and job security for at least some groups of workers (Neumark, 2000). The apparent rise in the use of temporary help, outsourcing, and contractors through the 1990s (Abraham and Taylor 1996) drew attention to a growing sector of nonstandard or "contingent" jobs that were likely less stable and less secure than more traditional employment (Kalleberg 1997; Houseman and Polivka 2000). The interest in understanding the causes of job loss and contingent work are both motivated by the concern that these developments make labor market prospects worse for individuals.

Tight labor markets at the end of the 1990s brought attention to another aspect of job loss, this time from the perspective of employers who were trying to reduce voluntary turnover. The interest in examining employee retention reflects a long-standing research interest in psychology but is a relatively recent topic in other fields. Voluntary quits are empirically the largest component of turnover. But unlike involuntary job loss and contingent work, voluntary quits are largely seen as a problem for employers. 
The general concern about job stability and security in labor markets, then, encompasses three quite distinct processes: (1) the employer's decision to cut employees through layoffs or dismissals, or involuntary turnover; (2) the employee's decision to quit, or voluntary turnover; and (3) the employer's decision to shift employment toward more contingent arrangements. The analyses below consider all three processes. Contingent work is essentially an organizational-level characteristic, and one could argue that turnover rates are as well-certainly the practices designed to influence them are. ${ }^{1}$ We therefore focus on policies and practices that are seen as influencing turnover and contingent work and use the organization as the unit of analysis.

The particular issue we study is the relationship between the degree of external churning of jobs, as reflected in involuntary and voluntary turnover and contingent work, and the internal organization of work, most importantly the flexibility of that internal organization. A large body of research has focused on alternative or flexible work practices, which share characteristics with "high performance" work systems in emphasizing employee involvement and teamwork as mechanisms for organizing work. Most of the research attention given to these practices, though, has focused on claims concerning the consequences of using them for firms, typically estimating effects on productivity or firm performance (Ichniowski, et al. 1997; Cappelli and Neumark forthcoming). But other arguments, described in detail below, have explicitly asserted that these work practices also reduce voluntary and involuntary turnover as well as use of contingent work, substituting internal job flexibility for external job churning. The alternative view, associated with systems models, suggests that firms seeking flexibility will do so across all modalities and that we should expect to see external job churning and internal flexibility concurrently.

We examine evidence on these hypotheses using the 1997 National Employers Survey (NES), a national probability sample of establishments in the U.S. The NES includes data on (1) the organization of work at each establishment, (2) establishment-level voluntary and involuntary turnover, and (3) use of contingent workers at the establishment. Among characteristics of the organization of work, we focus on

\footnotetext{
${ }^{1}$ While some research has focused on the potential positive aspects of turnover (Dalton, et al. 1981), it is fair to say that most of the research has considered turnover as a problem to be addressed, both for employees and for employers, and has concentrated on how it might be reduced.
} 
those that are likely to reflect flexibility in workforce management, which-according to the hypothesis of substitutability between internal and external flexibility-allow employers to reduce job instability and insecurity. We also examine the two most common alternative hypotheses for turnover-that they are strongly influenced by wage premia and closely related to employee selection procedures-in part because the work practices we study may covary with these other determinants of turnover, in part to assess the quality and plausibility of our data, and in part to garner new evidence on these standard hypotheses.

\section{Theoretical Approaches and Hypotheses}

This section lays out the hypotheses that we study in this paper regarding the relationships between work practices, turnover, and contingent work, which come out of a number of theories and perspectives. Some of these are relatively standard hypotheses regarding the determinants of turnover, and hence our empirical evidence on these hypotheses should be viewed as reexamining existing results. Others relate more specifically to high performance work practices or contingent work, in which case the evidence is, as far as we know, the first of its kind based on a representative sample of establishments.

\section{Standard Turnover Hypotheses}

First, as Osterman (1987) observed, there are many different theoretical frameworks for explaining employee turnover in organizations. Economists and psychologists, for example, developed arguments indicating that the quality of the match between jobs and workers would reduce both voluntary turnover and the component of involuntary turnover associated with dismissals (e.g., Hunter and Schmidt 1982; McCall 1990). The translation to workplace practices seems straightforward-employers who spend more time and effort in selecting employees should have better matches and lower turnover, leading to the hypothesis:

H1: Employers investing more in employee selection, other things equal, should have lower voluntary and involuntary turnover.

Subsequent research in economics pursued arguments about wage policies-"efficiency" wages-that lead to wage premiums that create incentives to reduce both voluntary turnover (Salop 1979) and the 
component of involuntary turnover associated with dismissals for malfeasance or "shirking" (Shapiro and Stiglitz 1984). While efficiency wage models may reduce dismissals for cause, firings are a small proportion of involuntary turnover, and the data we use (see below) cannot separate firings from overall involuntary turnover. Therefore, the efficiency wage relationship should be mainly for voluntary turnover. Wage premiums may also signal better matches that, other things equal, may be associated with lower levels of involuntary turnover.

The arguments about wages and voluntary turnover in one form or another have a long history, albeit often under different headings, and were more or less accepted empirically by those who studied turnover earlier (see, e.g., Price 1977), although some recent research has failed to find support for them (see, e.g., Powell et. al 1994; Kim 1999). But in theory, wage premiums translate clearly into strategies for employers to follow to reduce turnover, implying the hypothesis:

H2: Employers whose wages are higher, other things equal, should experience lower voluntary turnover, and perhaps also lower involuntary turnover.

\section{Voluntary Turnover}

As noted above, the psychological literature on turnover focuses heavily on the voluntary turnover decisions of individuals. Most of these arguments begin with an individual's affective response to a job, such as satisfaction or perceptions of met needs (Mobley 1982; Hom and Griffith 1995). Arguably the strongest theoretical statements about voluntary turnover and withdrawal behavior generally are those that trace it to individual commitment (Mowday, et al. 1982). Related arguments trace the relationship between work practices and commitment, especially practices associated with employee involvement (see Cotton 1993). Finally, some empirical research has examined the relationship between practices that generate employee involvement, particularly the practices associated with high performance work systems (see below), and voluntary turnover directly, finding a negative and significant relationship (Wilson, et al. 1990; Buch 1992; Arthur 1994; Huselid 1995). This theoretical and empirical work supports the hypothesis: 
H3: Employers with teamwork and related practices, other things equal, should experience lower voluntary turnover.

\section{Flexible Employment Systems, Involuntary Turnover, and Contingent Work}

Most intimately related to the main focus of this paper have been a series of arguments about systems of employment that are thought to reduce turnover, most notably involuntary turnover. The historical evidence regarding employer efforts to reduce turnover (particularly involuntary turnover) beginning in the early 1900s included employer policy decisions to bear the costs of carrying some excess workers, collective bargaining agreements that made layoffs more difficult and costly, and internal labor market arrangements such as internal promotions (see, e.g., Jacoby 1984). The more contemporary arguments began in the U.S. during the 1980s with discussions of Japanese management practices, where the assertion was that the practice of lifetime employment, at least among the leading firms that pursued it, was made possible by a series of other practices that provided increased flexibility of workforce management, such as job rotation, and thus reduced the incentive of firms to lay off workers for cyclical or structural reasons (Ouchi 1981; Aoki 1988). Related arguments about how committed and highly skilled workforces could achieve the flexibility of operations needed to stabilize employment were put forward based on European examples of smaller firms with arrangements based on employees making decisions and taking action themselves without being directed by management (Piore and Sabel 1984). These arguments suggested that firms that were internally flexible could become responsive and competitive in their product markets, and were particularly important in Europe, where the general impression was that government employment regulations and union restrictions were impeding the competitiveness of firms by reducing their ability to adapt and respond to changing competitive circumstances.

Atkinson (1984) articulated the choice available to employers to meet the need for flexibility that forms the basis for a model of substitutability between external job churning and internal job flexibility. In particular, he argued that firms could be "functionally flexible," with work organized so that a stable cohort 
of skilled, cross-functional employees adapt their work and, in turn, the firm, to changes in product demand. Or firms could be "numerically flexible," adjusting the workforce itself to changes in demand, hiring to bring in new skills as needed and, presumably, implementing layoffs to eliminate redundant or obsolete skills, as well relying more on "contingent" work. The more sophisticated version of this argument assumes a continuum between the two where greater functional flexibility reduces the need for numerical flexibility.

The distinction between functional and numerical flexibility has been used not just conceptually but in empirical studies of employment systems around the world including, for example, Finland (Penn, et al. 1992), Canada (Grenier, et al. 1997; Pinfield and Atkinson 1988), South Africa (Horowitz 1995), Singapore (Sharna and Luh 1994), Germany, Japan, and France (Lorenz 1992), and especially Britain, where the empirical debate over the extent of functional versus numerical flexibility was particularly intense (for a survey of the debate, see Hunter, et al. 1993).

These arguments for the most part are based on (and have been examined with) manufacturing cases, where the notion is that product markets are changing in ways that require responses that represent innovations of existing products rather than entirely new paradigms-e.g., car buyers want more variety and more frequent changes in models, but they still want cars as we know them. Innovations in existing products are examples of changes that could best be accommodated by a flexible workforce of experienced employees. If, on the other hand, customers demanded new products that were completely different from the previous ones, it is not so obvious that the current workforce would have the skills and abilities to produce them, and therefore not clear that the changes could be accommodated without churning the workforce.

The research focuses mainly on the extent of these practices, and a quick summary suggests much greater reliance by employers on numerical flexibility. In the U.S., there has been some empirical research on choices of employment systems along criteria similar to functional and numerical flexibility (see Smith 1997 for a review). But for the most part research has focused on examining the extent of numerically flexible arrangements in the economy as a whole, particularly the use of non-standard work (e.g., Kalleberg 1997). Aside from case studies, the question of whether functionally flexible practices actually reduce 
involuntary turnover and contingent work has not been addressed.

Which practices constitute a functionally flexible system of work organization is not perfectly clear from the prior research, but it would seem that the central elements are team-based systems where employees are allowed to initiate decisions, job rotation and other aspects of explicit flexibility, and ancillary practices that support the above. In practice, the characteristics of functionally flexible firms seem very much like those of high performance work systems, especially the emphasis on teamwork and job rotation. Indeed, some researchers use the term "flexible work places" as a synonym for high performance work practices (Gittleman, et al. 1998). But there is a distinction in theory. As Huselid (1995) observes, the hypotheses from the high performance literature are for voluntary turnover and relate to effects through the perceptions of individuals. The arguments about functionally flexible firms, in contrast, are for involuntary turnover and relate to organizational-level patterns of adjustment.

The literature on high performance work practices does posit some relationships with involuntary turnover, with the argument that job security is a necessary condition for the successful introduction of high performance work systems. Specifically, this line of reasoning tends to be that employees need protection from layoffs associated with productivity improvements in order to make high performance work systems successful; employees do not want to suggest improvements that would cause their own jobs to be cut, and at a psychological level, reciprocity causes them to respond to the employer's promise of security with their own promises of involvement (Kochan and Osterman 1994). To the extent that high performance work systems and functionally flexible firms are similar, these arguments suggest that functional flexibility and numerical flexibility are substitutes and not complements.

We therefore explicitly consider the hypothesis:

H4: Employers with more functionally flexible work systems, other things equal, should have lower rates of involuntary turnover through reduced layoffs, and less use of contingent work. 
An alternative perspective is that functional flexibility and numerical flexibility may be more complementary than substitutable. Employers facing the need for a great deal of operating flexibility may find that it is easiest to secure it by using both internally flexible systems and external job churning. Simple arguments about diminishing returns suggest that it may be more effective to put one's efforts into multiple mechanisms to achieve a given result than into only one. Models from systems approaches make similar predictions and have been illustrated in employment contexts with examples like Katz's (1985) description of how various aspects of the employment system in the auto industry, including both functional and numerical flexibility, adjusted to accommodate the need for change in that industry.

There is also empirical evidence to suggest that functional and numerical flexibility may go together. For example, Rodgers (2000) examines the above hypothesis that employment security is required for high performance work systems and finds relatively weak evidence for that position in prior studies. The studies that examined relationships between layoffs and high performance work systems find little evidence that they are substitutes. In a cross-sectional study, Drago (1996) finds essentially no relationship between the two. In longitudinal studies, Cappelli (2000) finds some evidence that both overall declines in employment and downsizing narrowly defined were related to at least some practices associated with these work systems, and Osterman (2000) finds a positive relationship between the introduction of high performance work systems and the incidence of layoffs. Our analyses below, in contrast, examine turnover rates as opposed to layoff announcements or downsizings. Regardless, the above considerations lead to the alternative hypothesis to $\mathrm{H} 4$ :

H4': Internally flexible work systems are positively associated with external job churning, in particular involuntary turnover.

\section{The "Core-Periphery" Hypothesis}

Finally, we examine a related argument regarding the role that contingent work specifically plays in explaining job stability and security. But in this case the hypothesis is quite different, focusing on the 
interrelationship between different forms of external employment flexibility, rather than on the relationship between internal and external flexibility. The basic argument, which comes from organizational theory (Thompson 1977), is that organizations have "core" resources that are important to protect and insulate from outside forces such as the market. Some part of the workforce whose skills and abilities are crucial to the organization and also difficult to replace might fit the definition of a core resource. The second part of the argument is that firms require some degree of flexibility in their workforce-for example, adjusting the total amount of labor needed in a recession-which might not be achievable internally with the functional flexibility model. Because they do not want to get this flexibility at the expense of their core employees, they concentrate the adjustments on a "periphery" of the workforce consisting of workers who are less crucial to the organization. The obvious candidates for the periphery are workers and jobs that are not as crucial a part of the organization, whose "peripheral" status is institutionalized via employment on a “contingent" basis, especially temporary help and contract work.

In this model, known as the "core-periphery" model, job instability and insecurity are explicitly redistributed away from a core of permanent employees toward more casual workers on the periphery. Using the language above, it is an example of numerical flexibility where that flexibility has been redistributed. The example of Hewlett Packard, where outsourcing is manipulated to maintain stable employment and product market strategies are chosen to reduce employment swings (e.g., avoiding contract work), has long been a teaching case illustrating how business strategy can help ensure job stability (Beer and VonWerssowetz 1981). Detailed arguments about how firms can buffer employees from job insecurity by redistributing the risk of job loss have also been common (Dyer, et al. 1985).

The concept of a core-periphery organization was made popular by the business practice writings of Charles Handy (1991), and most of the contemporary debate about it has been in Europe (Hakim 1990) and especially Britain, where the contingent workforce is of significant size and has clearly been growing (Hunter, et al. 1993). Most of the research on the core-periphery approach has simply asked employers 
whether they make use of it. ${ }^{2}$ But in a survey in the U.S. asking employers about their reasons for using temporary help, outsourcing, and subcontracting, "providing a buffer for regular staff against downturns in demand," which replicates the core-periphery argument, was one of the least frequently cited explanations for these changes (Abraham 1990). And there have been few efforts to examine whether this model actually works, aside from case studies like those above. The core-periphery model implies:

H5: Greater use of contingent work, other things equal, is associated with lower levels of involuntary turnover.

There is an obvious alternative hypothesis to the core-periphery model that follows the same arguments as those noted above for the functional flexibility model, which is that greater use of a contingent workforce may be a complement, rather than a substitute, for numerical flexibility. Employers who need flexibility may pursue it by using numerical flexibility/layoffs and greater use of contingent work. Again, it may be more efficient to use multiple methods to achieve a given goal, leading to:

H5': Employers making greater use of involuntary turnover will also use more contingent work.

\section{Data, Variables, and Tests}

\section{Data}

Our data come from an establishment-level survey of employment practices conducted by the U.S. Bureau of the Census for the National Center on the Educational Quality of the Workforce. The original National Employers Survey (NES I) was administered by the Bureau of the Census as a telephone survey in August and September of 1994, and the survey was repeated in August of 1997 (NES II). The sampling frame was drawn from the Census Bureau's Standard Statistical Establishment List (SSEL), targeting

\footnotetext{
${ }^{2}$ Less than ten percent of the U.K. workforce is with employers who report that they had a conscious coreperiphery labor strategy (Hunter, et al. 1993).
} 
business establishments throughout the United States, excluding those with fewer than 20 employees, and public-sector employers, non-profit institutions, and corporate headquarters. The survey oversampled establishments in manufacturing, and establishments with more than 100 employees. ${ }^{3}$ Because of this, it is important to use the sample weights to obtain estimates representative of the population of sampled establishments. We also report limited results weighting by employment size category, which provides employment-weighted estimates. We do not believe this is appropriate for testing hypotheses about establishment behavior, but it is useful if one wanted to try to use these estimates to make predictions regarding changes in work systems for turnover behavior as measured in surveys of workers. Finally, we report results for all establishments (using the sample weights), and separately for non-manufacturing and manufacturing establishments. ${ }^{4}$

In administering the NES, the target respondent was the plant manager in the manufacturing sector and the local business site manager in the non-manufacturing sector. Other surveys have targeted the human resource manager. But the goal was to measure how work is actually done in the facility, not the policies that might exist in employee handbooks, so the best person to ask about actual operating practices was the person in charge of operations in the establishment, not the manager in charge of personnel policies. The questionnaire was designed to allow for multiple respondents so that information could be obtained from establishments that kept financial information, for example, in a separate office-typically at corporate headquarters for multi-establishment enterprises. Computer Assisted Telephone Interviewing (CATI) was used to administer each survey. ${ }^{5}$

\footnotetext{
${ }^{3}$ The sample for the NES II has three additional components, including: an oversampling of states involved in particular educational reform efforts (2,000 completed interviews in California, Kentucky, Michigan, Maryland, and Pennsylvania); approximately 2,500 completed interviews that comprise a representative sample of the rest of the United States (45 states plus the District of Columbia); and a longitudinal component of about 900 completed interviews with business establishments that had participated in the NES I.

${ }^{4}$ Given the differences we report between the manufacturing and non-manufacturing sectors, the most empirically significant consequence of failing to use the sample weights is to assign too much weight to manufacturing establishments; in particular, unweighted estimates looked relatively more like those reported for manufacturing.

${ }^{5}$ Additional details on the NES data are provided in Cappelli and Neumark (2000).
} 


\section{Variables}

Despite many similarities between NES I and NES II, only in NES II were establishments asked to report their rates of voluntary and involuntary turnover and their use of contingent workers, so our analysis is restricted to the second survey. ${ }^{6}$ Specifically, regarding turnover, establishments in the NES II were asked to report the percentage of their permanent workforce that left either voluntarily or involuntarily (separate questions) in the past year. The two turnover questions ask "What percent, or how many, of your permanent workforce left voluntarily (e.g., retired or quit)/involuntarily (e.g., were fired or laid off) in the past year?" Most respondents gave a percentage response, and the remaining responses were converted to percentages at the Census Bureau. With respect to contingent workers, establishments in the NES II are asked whether they had any contract, leased, or temporary agency workers who were not employees of the

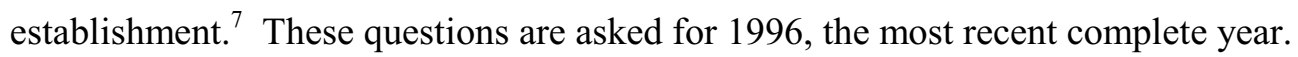

The more difficult issue is to find variables that identify work organization systems associated with the internal flexibility model. As noted above, the core element in this model appears to be team-based work systems. These are measured in our data with (1) a general variable measuring the percentage of workers involved in regular meetings to discuss work-related problems, (2) a more specific variable measuring the percentage of non-supervisory workers in self-managed teams, (3) the percentage of workers involved in job rotation, a practice associated with the reallocation of work, and (4) profit-sharing, the practice that many observers see as most crucial to supporting employee involvement in that it creates a

\footnotetext{
${ }^{6}$ The only measure available on both surveys asks about the percentage of workers with less than one year of tenure. The tenure question is not quite as useful, because it can be strongly influenced by establishment growth irrespective of turnover, although in principle we could control for growth using questions regarding growth in the workforce. However, the more significant problem is that this question differs across the surveys, asking about currently employed workers in NES I, and current permanent workers in NES II. Thus, changes in this tenure variable could reflect a number of things not necessarily related to turnover. ${ }^{7}$ The NES also has information on part-time workers. Part-time employment is sometimes included in definitions of nonstandard work and contingent work. But part-time work may well be steady and predictable, especially voluntary part-time work, and we have no information on voluntary vs. involuntary part time. We therefore do not study part-time employment.
} 
financial incentive for workers to act in the interest of the organization. ${ }^{8}$ These variables are used to address hypotheses $\mathrm{H} 3$ and $\mathrm{H} 4$ (and H4').

There are two other variables available in the NES II that may reflect internal flexibility. First, we include a variable asking whether the establishment has undergone re-engineering in the past three years, a process that is designed to restructure the internal operations of an organization to improve performance. One can think of this variable as providing a measure of, and a control for, the demand for change and the flexibility required to achieve it across organizations. Second, we include a variable measuring whether the establishment participated in benchmarking programs to learn about practices from other organizations. ${ }^{9}$ Again, this may be an indicator for establishments that are making (or have recently made) efforts to reevaluate and possibly redesign production or management methods, and therefore of establishments that are pursuing functional flexibility. However, we have to interpret the estimated coefficient of this variable cautiously, because it has other possible interpretations. In particular, benchmarking might be taken as an indicator of whether an establishment is simply a good or "best practice" employer seeking the best methods, which, as a result, has low turnover. In this case, we might think of benchmarking as a control variable for establishments that have low turnover because they have fewer problems or are better run. Hypotheses H1 and H2 concern, respectively, the effects of employee selection procedures and wage premiums on turnover. We include two variables available in the NES II that are commonly used to measure the extent to which employers search carefully when hiring new employees. These are the number of applicants interviewed for each position and the number of weeks required to fill a position. These questions are asked for the "typical" worker, and may serve as a proxy for overall selection practices for the establishment, although the question regarding weeks required to fill the position could also reflect tightness of labor markets. In addition, we include a variable measuring the wage premium for the establishment. This is estimated as the residual from a regression of log average salary of permanent workers on controls for education and occupational composition of the workforce, industry and size controls, and the share of

\footnotetext{
${ }^{8}$ Other research has found a direct relationship between profit-sharing practices and voluntary turnover (Wilson, et al. 1990).

${ }^{9}$ Neither the re-engineering nor the recruiting variables are available in NES I.
} 
hours that are overtime. ${ }^{10}$ Some observers believe that the kind of work systems that make use of team work and employee involvement also typically include other practices such as more intensive selection and higher wages (e.g., Appelbaum and Batt 1994). Under this interpretation, including the selection and wage premium variables allows us to estimate the independent effects of these other internal flexibility variables.

Finally, we also examine the relationships between turnover and contingent work, on the one hand, and whether skill requirements have risen or declined in the past three years for the typical worker. This issue of changing skill needs does not necessarily relate directly to internal flexibility, although changing skill needs may reflect a need for flexibility in terms of either acquiring skilled workers (internally or externally) if skill needs are rising, or shedding them if skill needs are falling. But it is an important issue generally in discussions about how the economy may be changing, and it is interesting to see the relationships with turnover and contingent work.

Aside from these key variables, we extract numerous variables used as controls from the NES II, which previous research has identified as potential factors driving turnover (e.g., Cotton and Tuttle 1986). These include: the percentage of non-managerial and non-supervisory workers covered by collective bargaining; the percentages of permanent employees that are women or minorities; the percentages of the permanent workforce in each of five occupational categories; the number of months required for a typical worker to become fully proficient; establishment size (five categories); and controls for workforce education, age of equipment and machinery (as a proxy for plant age, which is unavailable in the NES II), and two-digit industry, the latter two of which may be associated with establishment instability and the risk of job loss.

Tests

Hypotheses H1 through H4 (and H4') posit a relationship between establishment-level practices (employee selection, wage premiums, or work systems or practices) and turnover. Generically denoting the

\footnotetext{
${ }^{10}$ Whether establishment characteristics should be included depends on whether one believes that wage differences associated with these characteristics reflect differences in worker skills or wage premia (for evidence, see Blackburn and Neumark (1992) and Brown and Medoff (1989)). All of the specifications reported in the paper were also estimated using a wage premium constructed from a regression dropping the size and industry controls, with little effect on the results.
} 
vector of practices $\mathrm{P}$, and the individual turnover measure under consideration $\mathrm{T}$, we ideally want to estimate the causal effect of $\mathrm{P}$ on $\mathrm{T}$, controlling for other exogenous establishment-level variables (denoted X) that might explain variation in turnover, but are not central to our hypotheses. This leads to empirical models that we estimate of the form:

(1) $T_{i}=\alpha+P_{i} \beta+X_{i} \gamma+\varepsilon_{i}$.

When we estimate these equations for turnover rates, we use Tobit models with a lower tail of zero. When we estimate equations for the use of contingent workers, we use probit models.

There are some limitations of our analysis that must be kept in mind in interpreting the estimates. First, there may be establishment-level characteristics that are unmeasured, but correlated with both P and T, biasing the estimate of $\beta$. Of course, the most direct way to address this issue is to control for as many variables as possible that might affect turnover, leaving random determinants and measurement error in the error term. We believe that we are able to extract a long and fairly complete list of such controls using the NES II. Nonetheless, we cannot rule out this possibility.

One step we cannot take, however, is to estimate a first-difference model using NES I and NES II (for which there is a smaller, overlapping set of establishments). In principle this would be useful because it addresses the question of changes in turnover that occur with changes in work practices and other variables, providing an experiment that nets out at least those establishment-level characteristics that are fixed over time. However, this is impossible because the turnover measures are only available in NES II. It is possible in principle to examine the relationship between changes in work practices and levels of turnover and the use of contingent work, but there are at least two problems in doing so. First, we have some skepticism regarding the accuracy of measured changes in work practices and other variables over the short three-year window afforded by the two surveys (see Cappelli and Neumark 2000). And second, it is not obvious what relationship one should expect between changes in practices, on the one hand, and levels of turnover and the incidence of contingent work, on the other. 
Thus, we are left with cross-sectional estimates that tell us how turnover or use of contingent work at a point in time is associated with a variety of employer practices and other variables. ${ }^{11}$ Aside from the caution we should exercise in interpreting such associations causally because of unobserved establishmentlevel characteristics, we also have to be concerned that rather than internal flexibility determining the extent of external churning, they may both be driven by changes in product markets or technology, or other developments. Longitudinal data per se cannot address this problem. In our empirical specifications, however, we control for numerous establishment-level characteristics, including Census two-digit industry dummy variables, size, etc., so we are inclined to rule out important changes within industries (and the other categories for which we control) that could generate a spurious relationship.

Finally, internal and external flexibility may be jointly determined. The ideal experiment is one in which establishments would vary work practices, and then passively let turnover and contingent work adjust. But this may not be how the data are generated. Another way to think about this problem is that we are interested in evidence on whether internal flexibility and external job churning are substitutable or complementary, but we do not have a source of exogenous variation to identify causal effects; a counterexample would be exogenous price variation that is used to answer questions regarding substitutecomplement relationships for standard production inputs in the economic analysis of production functions.

With respect to hypothesis H5 (and H5'), these limitations regarding joint determination of variables are even sharper, as this hypothesis concerns the association between involuntary turnover and the use of contingent work. Denoting the former as IT, and the latter as CW, we estimate regressions of the form:

(2) $\quad \mathrm{IT}_{\mathrm{i}}=\alpha^{\prime}+\mathrm{CW}_{\mathrm{i}} \beta^{\prime}+\mathrm{X}_{\mathrm{i}} \gamma^{\prime}+\varepsilon^{\prime}{ }_{\mathrm{i}}$.

Clearly in this case (and under the core-periphery hypothesis) we are considering two types of employment policies chosen jointly, so the estimates should not necessarily be interpreted causally, but rather simply as telling us the partial correlation between involuntary turnover and contingent work after

\footnotetext{
${ }^{11}$ The questions regarding re-engineering and skill changes are somewhat different in that they ask retrospective questions about changes over time.
} 
controlling for the variables in X. In estimating equation (2), we do not condition on the other employer practices related to functional flexibility, because the assertion of the core-periphery hypothesis is not necessarily that establishments with the same practices will explicitly trade off stability and security for "permanent" workers with reliance on contingent work, but rather that establishments may put in place sets of practices related to flexibility that generate this tradeoff, in which case the inclusion of these practices could represent "over-controlling."

\section{$\underline{\text { V. Results }}$}

\section{Descriptive Statistics}

To begin, we present some basic descriptive statistics on voluntary turnover, involuntary turnover, and use of contingent work. There are few, if any, other sources of representative data on these variables, and the descriptive results are therefore interesting in their own right. Table 1 reports the means for theseoverall, and broken out by industry and establishment size. Turnover rates vary quite widely across industry, with the voluntary turnover rate ranging from .065 in utilities to .395 in hotels. Among other industries with high voluntary turnover rates are textiles and apparel, communications, retail, and business services, while those with low rates include insurance and real estate, printing and publishing, and chemical and petroleum industries. Involuntary turnover rates are lower on average, and vary somewhat less, with a low of .022 in utilities, and a high of .119 in hotels. Involuntary turnover rates are also high in textiles and apparel, printing and publishing, and transportation equipment, and low in machinery and instruments, communications, finance, and health services. Finally, 41.7 percent of establishments report using some contingent workers, with use particularly common in printing and publishing, chemical and petroleum, other and miscellaneous manufacturing, and communications, and much less common in retail trade. By size category, with the exception of the smallest establishments, turnover rates generally decline with size, while the use of contingent workers goes up with size (which may be because our variable measures incidence, not the proportion of labor supplied by contingent workers). 
In Table 1 we also report statistics for two simple consistency checks, to assess the reliability of the data. ${ }^{12}$ The first consistency check is with union status, where we verify that these data replicate the wellknown finding that union representation is associated with lower quit rates. The second consistency check is with respect to changes in the size of the establishment's workforce over the last three years. We would expect, for example, that establishments that are shrinking would have greater involuntary turnover, and vice versa, which we find.

We begin our analysis of the relationship between external churning and internal flexibility in Table 2, which presents descriptive statistics relating the three aspects of job instability and insecurity to the work practices associated with functional flexibility. In each case, we use a categorical distinction between the work practices, transforming those reported as a percentage of workers involved into a "yes/no" distinction based on whether this percentage is greater than zero. In the means, nearly every work practice related to functional flexibility (meetings, self-managed teams, job rotation, and profit sharing) is associated with higher voluntary turnover, higher involuntary turnover, and greater likelihood of using contingent workers, and most of these differences are statistically significant at the five-percent level. The same is generally true of re-engineering and benchmarking, where in five of the six comparisons reported these are associated with more external churning, with the differences statistically significant at the five-percent level in four of these comparisons. The only exception is the relationship between benchmarking and voluntary turnover, with this turnover measure significantly lower in establishments using benchmarking.

The findings with respect to changes in skill requirements are more ambiguous. First, there are relatively few establishments reporting declining skill requirements, but many reporting either no change or increases. Comparing the latter two, increasing skill requirements are significantly associated with lower involuntary turnover (although the small set of establishments indicating declining skill requirements also has lower involuntary turnover). But increasing skill requirements are significantly associated with greater use of contingent work, comparing either establishments with skill increases to those with no change, or

\footnotetext{
${ }^{12}$ We report all the descriptive statistics in this panel of the table, but highlight those pertinent to the consistency check.
} 
those with no change to those with decreases. This suggests that these firms are using contingent work in part to meet skill needs they cannot easily meet via adjustments among their permanent workers.

The overall message from the comparisons of means is much more consistent with the view that internal flexibility is complementary to external churning, as the associations are mostly strongly positive between work and management practices associated with functional flexibility, on the one hand, and voluntary turnover, involuntary turnover, and contingent work, on the other. Next, we explore these relationships in a multivariate framework, controlling for (1) the simultaneous use of the various functionally flexible practices, (2) other variables that are hypothesized to determine turnover (selection and wages), and (3) establishment and worker characteristics that may be correlated with both turnover and the variables describing work organization.

\section{Voluntary Turnover}

Table 3 reports estimates of models for voluntary turnover. We estimate one-tailed Tobit models to account for the left-censoring of the data. In the first column, we use a specification simply including the six variables that we regard as most clearly related to functional flexibility. ${ }^{13}$ For the most part, the relationships from the bivariate comparisons in Table 2 are unchanged, with meetings, job rotation, profit sharing, and re-engineering positively associated with voluntary turnover (although only at the ten-percent level for re-engineering), while benchmarking retains a significant negative relationship. The one exception is for self-managed teams, for which the estimated relationship becomes negative (and statistically significant). In column (2) we add the variable capturing skill changes, which indicates that skill decreases are associated with lower voluntary turnover.

The specification in column (3) adds the variables capturing selection practices and wage premia, to test the principal standard hypotheses $(\mathrm{H} 1$ and $\mathrm{H} 2)$ regarding the determinants of turnover. As hypothesized, voluntary turnover is significantly negatively related to both the intensity of selection procedures and the wage premium paid by the establishment. Among the work practice variables, the

\footnotetext{
${ }^{13}$ All variable measuring rates or percentages are defined as proportions ranging from zero to one, so, for example, the coefficient of .078 for the meetings variable implies that a ten-percent increase in workers involved in meetings (a .1 increase in the proportion) increases the voluntary turnover rate by .0078.
} 
estimated coefficients of the four "core" practices are little changed, but re-engineering and benchmarking are no longer significantly related to voluntary turnover. In column (4), however, when the full set of establishment and worker controls are included, the changes are somewhat sharper. Among the proxies for functional flexibility, only meetings and job rotation remain significantly related to voluntary turnover, with the association positive for both variables. These results, of course, are more consistent with functional flexibility being complementary with external churning as reflected in voluntary turnover. The wage premium effect remains strongly negative, while the evidence regarding selection becomes less clear-cut. The estimated coefficient of the number of candidates interviewed is strongly negative, but that of weeks to fill the opening is positive. Recall, though, our earlier concern that the latter variable may also reflect market conditions; a positive coefficient is consistent with tight labor markets associated with both high turnover (as quits are higher) and more difficulty finding candidates. Thus, candidates interviewed is probably a more reliable indicator of selection intensity, and consistent with more intensive selection reducing voluntary turnover. Column (5) reports estimates of the same specification on an employmentweighted basis, with little difference except that the estimated association between profit sharing and voluntary turnover becomes statistically significant.

Finally, columns (6) and (7) report results for specifications estimated separately for manufacturing and non-manufacturing establishments. The differences are rather striking. The results for nonmanufacturing establishments largely mimic those for the full sample (column (4) is most comparable), with the exception of a stronger positive relationship between self-managed teams and voluntary turnover. On the other hand, the nature of the evidence for manufacturing establishments is substantially different. For three of the core functionally flexible practices (self-managed teams, job rotation, and profit sharing), as well as the variable capturing increased skill requirements, the evidence points to significant negative associations with voluntary turnover; only for meetings is the evidence in the positive direction. At the same time, the evidence regarding the "standard" explanations of voluntary turnover-selection and wages-is similar to that for non-manufacturing establishments, which bolsters the validity of the conflicting evidence for functionally flexible practices. 
Bringing together the results, while the overall evidence indicates that internal flexibility goes hand in hand with voluntary turnover, a result that contradicts the behavioral models postulating a trade-off between these, it also appears that this depends very much on whether we look at manufacturing or nonmanufacturing. While the answer is the same for non-manufacturing establishments, the evidence for manufacturing establishments is more consistent with substitution between internal flexibility and external churning.

\section{Involuntary Turnover}

Table 4 turns to involuntary turnover, presenting estimates of the same specifications as those in Table 3, but with the involuntary turnover rate as the dependent variable. In the bivariate comparisons in Table 2, the relationships with internally flexible practices were weaker for involuntary than for voluntary turnover. Nonetheless, when we add all of these practices simultaneously, as well as the indicators for changes in skill requirements, statistically significant relationships with involuntary turnover remain. In particular, job rotation, profit sharing, re-engineering, and benchmarking are significantly positively associated with involuntary turnover, evidence that is consistent with complementarity between internal flexibility and external churning, and more directly here, as involuntary turnover is more likely the result of employers' decisions or actions. We also find that increased skill requirements are associated with decreased involuntary turnover, more consistent with employers attempting to retain skilled workers, rather than replacing workers whose skills are too low. Finally, we find that although the wage premium is unrelated to involuntary turnover, intensity of employee selection (in this case, though, via the weeks to fill opening variable) appears to reduce this type of turnover, although again this could reflect tightness in labor markets, which increases voluntary turnover but reduces involuntary turnover.

When the full set of controls is added, in column (4), the estimated relationships between involuntary turnover and functionally flexible practices weaken, with only re-engineering and profit sharing retaining statistically significant associations (and the latter only at the ten-percent level). Nonetheless, it is noteworthy that both estimated associations are positive, which again is inconsistent with substitutability 
between internal flexibility and external churning. In column (5), using employment-weighted estimates, the evidence becomes a bit stronger for profit sharing.

Finally, columns (6) and (7) report estimates for subsamples of non-manufacturing and manufacturing establishments. As for voluntary turnover, the results for non-manufacturing establishments mirror those for the full sample, showing positive relationships between functionally flexible practices and external churning (although for a different set of such practices than in the results for voluntary turnover). For manufacturing, in contrast, the estimates point to some significant negative associations between these practices and external churning, in particular with regard to self-managed teams and profit sharing (the latter at the ten-percent level), although the estimated association for re-engineering is positive, as for nonmanufacturing establishments. Thus, again, the overall evidence is generally more consistent with complementarity between internal flexibility and external churning in the non-manufacturing sector, but substitutability in the manufacturing sector.

\section{Contingent Work}

While the previous two tables look at the conventional voluntary and involuntary turnover rates as measures of external churning, Table 5 looks at use of contingent work, the growth of which is a relatively recent phenomenon, but one that appears to associated with less stable employment (Houseman and Polivka 2000) and hence is an alternative indicator of external job churning, although of a different variety. We report results from probit models, after transforming the coefficient estimates to give the partial derivatives of the probability of using contingent workers with respect to the independent variables. ${ }^{14}$ The estimates in columns (1)-(4) are qualitatively quite similar, with the exception of self-managed teams, which goes from having a significant relationship in the first three columns to an insignificant one in the fourth. Jumping right to column (4), then, we see that there are no estimated relationships between functionally flexible work practices and use of contingent work that are negative, and a few that are positive and statistically significant, including profit sharing, re-engineering, and benchmarking, as well as increased skill needs

\footnotetext{
${ }^{14}$ The standard errors are adjusted to provide the same t-statistics as on the original probit coefficient estimates.
} 
(which has alternative interpretations). The first two of these relationships persist in the employmentweighted estimates.

Once again, the estimates for non-manufacturing establishments are similar to those for the full sample. The estimates for manufacturing establishments again differ, but in this case we do not find evidence of opposite-signed associations between functionally flexible practices and external churning (in this case contingent work). Rather, among manufacturing establishments a positive association is evident for a different functionally flexible work practice-specifically, self-managed teams-and there is no evidence of negative relationships. Thus, in contrast to the results for voluntary and involuntary turnover, when we look at contingent work as a reflection of external churning, there is no evidence consistent with substitutability with internal flexibility, even for manufacturing. Instead, all of the evidence suggests that internal flexibility and external churning tend to be used in tandem, perhaps because of complementarity.

Finally, Table 6 turns briefly to the question of contingent work and the core-periphery hypothesis that greater use of contingent work will be associated with lower involuntary turnover, as churning is shifted from core permanent employees to peripheral non-permanent employees. We begin with the simple bivariate regression of the involuntary turnover rate on use of contingent workers, and in contrast to the core-periphery hypothesis, find a statistically significant positive association. When we add controls for the standard economic determinants of involuntary turnover, and the establishment and worker controls, this positive association strengthens. We do not include the variables capturing functionally flexible work practices because the core-periphery hypothesis does not concern them. Nothing in the core-periphery hypothesis rules out alternative internal work practices supporting both approaches to external flexibility. Finally, in columns (4)-(6) we report the employment-weighted estimates, and the estimates for nonmanufacturing and manufacturing establishments. In all cases, the positive association is robust. We do not find support for the core-periphery hypothesis in either the non-manufacturing or the manufacturing sector. Instead, the use of contingent work is positively related to numerical flexibility in the form of involuntary turnover, suggesting that these are complementary practices. 


\section{Conclusions and Discussion}

Our analysis uses a national probability sample of establishments to test hypotheses regarding job stability, job security, and contingent work, or churning of jobs that is external to the firm or establishment. Some of these hypotheses concern the "standard" economic determinants of turnover, including selection effort or intensity and the wage premium paid by the employer. The more unique focus of our study, though, is on the relationships between external job churning and flexible or "high performance" work systems. These work systems are presumed to give employers flexibility in managing their workforce, in terms of reorganizing, reallocating, or retraining their employees to respond to contingencies posed by changing markets, technologies, etc. One central hypothesis we examine is that external churning and internal flexibility are substitutable. While firms need flexibility to respond to change, they can obtain this in one of two ways, and all else the same, those relying more on external adjustments utilize less internal flexibility, and vice versa. Alternatively, external job churning may be more complementary with internally flexible systems, reflecting common influences that call for more flexible workforce organization, or because internally flexible systems lead to external churning. Finally, we examine the related "coreperiphery" hypothesis that employers choose between relatively high involuntary turnover among core employees, or reliance on flexible peripheral, largely contingent workers.

There are some limitations in trying to establish causal effects of flexible work systems on turnover and use of contingent work. Consequently, our findings should be viewed more as establishing the empirical relationships between the two after accounting for a rich array of establishment and workforce characteristics, as well as other determinants of turnover, and providing some evidence on the consistency of the data with the various hypotheses. They are not definitive causal estimates. Viewed in this light, though, the evidence paints a rather clear picture. First, with reference to "standard" determinants of turnover, the evidence is generally consistent with higher wage premia and more intense selection efforts reducing voluntary turnover. Second, we find that contingent work and involuntary turnover of the permanent workforce are positively and significantly related, contradicting the "core-periphery" hypothesis. 
Finally, focusing on the main empirical concern of this paper, the question of whether internal flexibility and external churning appear more substitutable or complementary receives a mixed answer. In manufacturing, the evidence regarding voluntary and involuntary turnover is more consistent with substitution between internal flexibility and external churning, which we interpret as to some extent consistent with existing case studies of this sector. However, contingent work is positively associated with internally flexible work practices even in manufacturing. In non-manufacturing, in contrast, internal flexibility and external churning-including both types of turnover and contingent work-are positively related. This is inconsistent with a tradeoff between them, and more consistent with common factors promoting flexibility along both internal and external dimensions, or greater internal flexibility also promoting external churning, perhaps because of complementarities.

On both an establishment and employment basis, non-manufacturing is by far the larger sector, which helps explain why our overall estimates are similar to those for non-manufacturing establishments alone. But why these relationships should be different between non-manufacturing and manufacturing is something of a puzzle. In particular, why the internally flexible practices that are associated with high performance work seem to increase voluntary turnover in the non-manufacturing setting and why, overall, they seem to be associated with higher involuntary turnover and more contingent work in that setting is difficult to explain. Part of the explanation may simply be that these work practices mean very different things in the two sectors. Job rotation, for example, has a very precise meaning in the context of a manufacturing operation where it is associated with overall approaches to managing production operations, such as Japanese management, which include protecting permanent employees. Here it is possible to see some evidence that the work practices we identify may generate something like internal flexibility that serves as a substitute for involuntary turnover. Even in manufacturing, however, it appears that management still pursues greater use of contingent work when it adopts functionally flexible work practices. Perhaps there is a hierarchy of options for achieving flexibility, and employers pursue internal flexibility and contingent work before relying on involuntary turnover. 
What these practices mean in the context of an insurance office, retail store, or some other component of the service sector is not so clear, however. In a restaurant or retail operation, for example, the variations in demand are not necessarily variations in the type of products that require employee creativity and input to solve. They are more likely to be variations in peak demand (such as increased business during holiday periods), which require adjustments in the pace of work and in work schedules, adjustments that may more clearly come at the expense of employees. Practices like self-managed teams and job rotation in service establishments, for example, may be signs that the organization is under pressure to operate with fewer workers, creating work demands that may exacerbate voluntary turnover. It may be that the decision to introduce the work practices described above in the service sector is an indication of especially great pressure to achieve flexibility, more than can be accommodated internally. Or the nature of production in this sector may simply entail more complementarities between internal and external flexibility.

At a minimum, these results imply that what we can learn about the relationships between internal flexibility and voluntary and involuntary turnover from studies of manufacturing establishments-with which most of the prior studies have been concerned-may be limited. In particular, these studies may not tell us a great deal about conditions faced by much of the workforce or most employers, for whom the spread of flexible or "high performance" work systems may be associated with decreased job stability and job security, and especially increased contingent employment. 


\section{$\underline{\text { References }}$}

Abraham, Katharine G. 1990. Restructuring the Employment Relationship: The Growth of MarketMediated Work Arrangements. In K. Abraham and R. McKersie (eds.), New Developments in the Labor Market: Toward a New Institutional Paradigm, Cambridge, MA: MIT Press, pp. 85-119.

Abraham, Katharine G., and Susan K. Taylor. 1996. Firms' Use of Outside Contractors: Theory and Evidence. Journal of Labor Economics, 14:3 394-424.

Aoki, M. 1988. Information, Incentives, and Bargaining. New York: Cambridge University Press.

Appelbaum, Eileen, and Rosemary Batt. 1994. The New American Workplace: Transforming Work Systems in the United States, Ithaca, NY: ILR Press.

Arthur, Jeffrey B. 1994. Effects of Human Resource Systems on Manufacturing Performance and Turnover. Academy of Management Journal, 37: 670-687.

Atkinson, James. 1984. Manpower Strategies for Flexible Firms. Personnel Management, 16(8): 28-31.

Baily, Martin N. 1974. On the Theory of Layoffs and Unemployment. Econometrica, 45: 1043-1064.

Beer, M., and R.O. Von Werssowetz. (1981). Human Resources at Hewlett-Packard, Boston: Harvard Business School.

Blackburn, McKinley, and David Neumark. 1992. Unobserved Ability, Efficiency Wages, and Interindustry Wage Differentials. Quarterly Journal of Economics, 107(4): 1421-1436.

Brown, Charles, and James Medoff. 1989. The Employer Size-Wage Effect. Journal of Political Economy, 97: 1027-1059.

Buch, Kimberly. 1992. Quality Circles and Employee Withdrawal Behaviors: A Cross-Organizational Study. Journal of Applied Behavioral Science, 28(1): 62-73.

Cappelli, Peter. 2000. Examining the Incidence of Downsizing and Its Effect on Establishment Performance. In D. Neumark (ed.), On the Job: Is Long-Term Employment a Thing of the Past?, New York: Russell Sage Foundation, pp. 463-516.

Cappelli, Peter, and David Neumark. Do "High Performance" Work Practices Improve EstablishmentLevel Outcomes? Forthcoming in Industrial and Labor Relations Review.

Cotton, John L. 1993. Employee Involvement: Methods for Improving Performance and Work Attitudes, Newbury Park, CA: Sage Publications.

Cotton, J.L., and J.M. Tuttle. 1986. Employee Turnover: A Meta-Analysis and Review with Implications for Research. Academy of Management Review, 11: 55-70.

Dalton, D.R., D.M. Krackhardt, and L.W. Porter. 1981. Functional Turnover: An Empirical Assessment. Journal of Applied Psychology 66: 716-721.

Drago, Robert. 1996. Workplace Transformation and the Disposable Workplace: Employee Involvement in Australia. Industrial Relations, 35: 526-543. 
Dyer, Lee, Fred Foltman, and George Milkovich. 1985. Contemporary Employment Stabilization Practices. In T. A. Kochan and T. A. Barocci (eds.), Human Resource Management and Industrialization: Text, Readings, and Cases, Boston: Little, Brown, pp. 203-214.

Feldstein, Martin. 1976. Temporary Layoffs in the Theory of Unemployment. Journal of Political Economy, 84: 937-958.

Gittleman, Maury, Michael Horrigan, and Mary Joyce. 1998. Flexible Workplace Practices: Evidence from a Nationally Representative Survey. Industrial and Labor Relations Review, 52: 99-115.

Grenier, J., A. Giles, and J. Belanger. 1997. Internal Versus External Labour Flexibility: A TwoPlant Comparison in Canadian Manufacturing. Relations Industrielles-Industrial Relations, 52: 683-711.

Hakim, Catherine. 1990. Core and Periphery in Employers' Workforce Strategies: Evidence from the 1987 E.L.U.S. Survey. Work, Employment and Society, 4: 157-188.

Handy, Charles. 1991. The Age of Unreason, London: Business Books.

Hom, Peter W., and Rodger W. Griffeth. 1995. Employee Turnover, Cincinnati: South-Western.

Horowitz, F. 1995. Flexible Work Practices in South Africa: Economic, Labour Relations, and Regulatory Considerations. Industrial Relations Journal, 26: 257-266.

Houseman, Susan N., and Anne E. Polivka. 2000. The Implications of Flexible Staffing Arrangements for Job Stability. In D. Neumark (ed.), On the Job: Is Long-Term Employment a Thing of the Past?, New York: Russell Sage Foundation, pp. 427-462.

Hunter, L., A. McGregor, J. MacInnes, and A. Sproul. 1993. The 'Flexible Firm': Strategy and Segmentation. British Journal of Industrial Relations, 31: 383-407.

Hunter, J. E., and F.L. Schmidt. 1982. Fitting People to Jobs: The Impact of Personnel Selection on National Productivity. In M. Dunnette and E. Fleishman (eds.), Human Performance and Productivity: Vol. 1, Human Capability Assessment, Hillsdale, NJ: Erlbaum.

Huselid, Mark A. 1995. The Impact of Human Resource Management Practices on Turnover, Productivity and Corporate Financial Performance. Academy of Management Journal, 38(3): 635-672.

Ichniowski, Casey, Kathryn Shaw, and Giovanna Premushi. 1997. The Effects of Human Resources Management Practices on Productivity: A Study of Steel Finishing Lines. American Economic Review, 87(3): 291-313.

Jacoby, Sanford. 1984. Employing Bureaucracy: Managers, Unions, and the Transformation of Work in American Industry, New York: Columbia University Press.

Kalleberg, A. L. 1997. Nonstandard Work, Substandard Jobs: Flexible Work Arrangements in the U.S., Washington, D.C.: Economic Policy Institute.

Katz, Harry C. 1985. Shifting Gears: Changing Labor Relations in the U.S. Automobile Industry, Cambridge, MA: MIT Press. 
Kim, Marlene. 1999. Where the Grass is Greener: Voluntary Turnover and Wage Premiums. Industrial Relations, 38(4): 584-602.

Kochan, Thomas, and Paul Osterman. 1994. The Mutual Gains Enterprise: Forging a Winning Partnership Among Labor, Management, and Government, Boston, MA: Harvard Business School Press.

Lorenz, E. H. 1992. Trust and the Flexible Firm: International Comparisons. Industrial Relations, 31: 455-472.

McCall, Brian P. 1990. Occupational Matching: A Test of Sorts. Journal of Political Economy, 98(1): 4569.

Medoff, James. 1979. Layoffs and Alternatives Under Trade Unions in U.S. Manufacturing. American Economic Review, 69: 380-395.

Mobley, W. H. 1982. Employee Turnover: Causes, Consequences, and Control, Reading, MA: AddisonWesley.

Mowday, Richard T., Lyman W. Porter, and William H. Mobley. 1982. Employee-Organizational Linkages, New York: Academic Press.

Neumark, David (ed.). 2000. On the Job: Is Long-Term Employment a Thing of the Past?, New York: Russell Sage Foundation.

Osterman, Paul. 1987. Turnover, Employment Security, and the Performance of the Firm. In M. Kleiner, R. Block, M. Roomkin, and S. Salsborg (eds.), Human Resources and the Performance of the Firm, Madison, WI: Industrial Relations Research Association.

Osterman, Paul. 2000. Work Reorganization in an Era of Restructuring: Trends in Diffusion and Effects on Employee Welfare. Industrial and Labor Relations Review, 53: 179-196.

Ouchi, William. 1981. Theory Z: How American Business Can Meet the Japanese Challenge, Reading, MA: Addison-Wesley.

Penn, R., K. Lilja, and H. Scattergood, H. 1992. Flexibility and Employment Patterns in the Contemporary Paper Industry: A Comparative Analysis of Mills in Britain and Finland. Industrial Relations Journal, 23: 214-223.

Pinfield, Lawrence T., and James S. Atkinson. 1988. Employment: The Flexible Firm. Canadian Business Review, 15(4): 17-19.

Piore, Michael, and Charles Sabel. 1984. The Second Industrial Divide, New York: Basic Books

Powell, Irene, Mark Montgomery, and James Cosgrove. 1994. Compensation Structure and Establishment Quit and Fire Rates. Industrial Relations, 33(2): 229-248.

Price, James L. 1977. The Study of Turnover, Ames, IA: The Iowa State University Press.

Rodgers, Ronald. 2000. Commitment-Based Employment Relationships and High Performance Work Systems: A Theory-Driven Research Strategy to Bring the Traditional Concepts in Line with the Empirical Evidence. Singapore: The National University of Singapore Faculty of Business 
Administration Working Paper.

Salop, Steven C. 1979. A Model of the Natural Rate of Unemployment. American Economic Review, 69: 117-125.

Shapiro, Carl, and Joseph E. Stiglitz. 1984. Equilibrium Unemployment as a Worker Discipline Device. American Economic Review, 74: 433-444.

Sharna, B., and L. L. Luh. 1994. Labour Market Flexibilities as HRM Strategies: The Example of Singapore. Journal of Asian Business, 10: 61-77.

Smith, Vicky. 1997. New Forms of Work Organization. Annual Review of Sociology, 23: 315-325.

Topel, Robert. 1984. On Layoffs and Unemployment Insurance. American Economic Review, 73: 541559.

Thompson. 1977. Organizations in Action, New York: McGraw-Hill.

Wilson, Nicholas, John R. Cable, and Michael J. Peel. 1990. Quit Rates and the Impact of Participation, Profit-Sharing and Unionization: Empirical Evidence from U.K. Engineering Firms. British Journal of Industrial Relations, 28(2): 197-211. 
Table 1: Mean Turnover Rates and Proportions Using Contingent Workers, by Industry and Size Category

\begin{tabular}{|c|c|c|c|c|}
\hline & \multicolumn{4}{|c|}{ Prop. Using any } \\
\hline & Voluntary & $\underline{\text { Involuntary }}$ & $\underline{\text { Contingent Workers }}$ & $\underline{N}$ \\
\hline & (1) & $(2)$ & $(3)$ & $(\overline{4})$ \\
\hline Full sample & .198 & .066 & .417 & 1840 \\
\hline \multicolumn{5}{|l|}{ Industry: } \\
\hline$\overline{\text { Food and tobacco }}$ & .143 & .060 & .545 & 129 \\
\hline Textiles and apparel & .215 & .089 & .471 & 86 \\
\hline Lumber and paper products & .156 & .065 & .409 & 130 \\
\hline Printing and publishing & .097 & .090 & .657 & 101 \\
\hline Chemical and petroleum & .079 & .051 & .669 & 98 \\
\hline Primary metals & .137 & .083 & .564 & 130 \\
\hline Fabricated metals & .120 & .049 & .496 & 111 \\
\hline Machinery and instruments & .103 & .033 & .525 & 133 \\
\hline Transportation equipment & .146 & .117 & .639 & 107 \\
\hline Other and miscellaneous manufacturing & .141 & .076 & .653 & 136 \\
\hline Construction & .106 & .056 & .450 & 82 \\
\hline Transportation services & .147 & .054 & .508 & 59 \\
\hline Communications & .207 & .043 & .698 & 29 \\
\hline Utilities & .065 & .022 & .625 & 60 \\
\hline Wholesale trade & .115 & .051 & .602 & 93 \\
\hline Retail trade & .296 & .084 & .165 & 68 \\
\hline Finance & .125 & .029 & .520 & 38 \\
\hline Insurance and real estate & .083 & .052 & .474 & 46 \\
\hline $\begin{array}{l}\text { Hotels, rooming houses, camps, } \\
\text { and other lodging places }\end{array}$ & .395 & .119 & .406 & 71 \\
\hline Business services & .256 & .059 & .539 & 61 \\
\hline Health services & .141 & .041 & .612 & 72 \\
\hline \multicolumn{5}{|l|}{ Size: } \\
\hline 20 to 49 & .164 & .065 & .358 & 332 \\
\hline 50 to 99 & .251 & .068 & .390 & 320 \\
\hline $100-249$ & .261 & .067 & .603 & 371 \\
\hline $250-999$ & .181 & .066 & .690 & 529 \\
\hline $1000+$ & .176 & .060 & .853 & 288 \\
\hline \multicolumn{5}{|l|}{ Consistency checks: } \\
\hline $\begin{array}{l}\text { Are any of your employees represented by } \\
\text { a union? (Yes/No) }\end{array}$ & $.124 / .207$ & $.062 / .066$ & $.485 / .409$ & $480 / 1360$ \\
\hline \multicolumn{5}{|c|}{$\begin{array}{l}\text { In the past three years, has the size of the } \\
\text { establishment's workforce increased, stayed the } \\
\text { same, or decreased? }\end{array}$} \\
\hline Increased & .167 & .053 & .475 & 811 \\
\hline Stayed the same & .230 & .071 & .344 & 630 \\
\hline Decreased & .174 & .088 & .488 & 395 \\
\hline
\end{tabular}

Estimates are sample weighted to be representative of establishments. 
Table 2: Mean Turnover Rates and Proportions Using Contingent Workers, by Employer Practices Related to Internal Flexibility

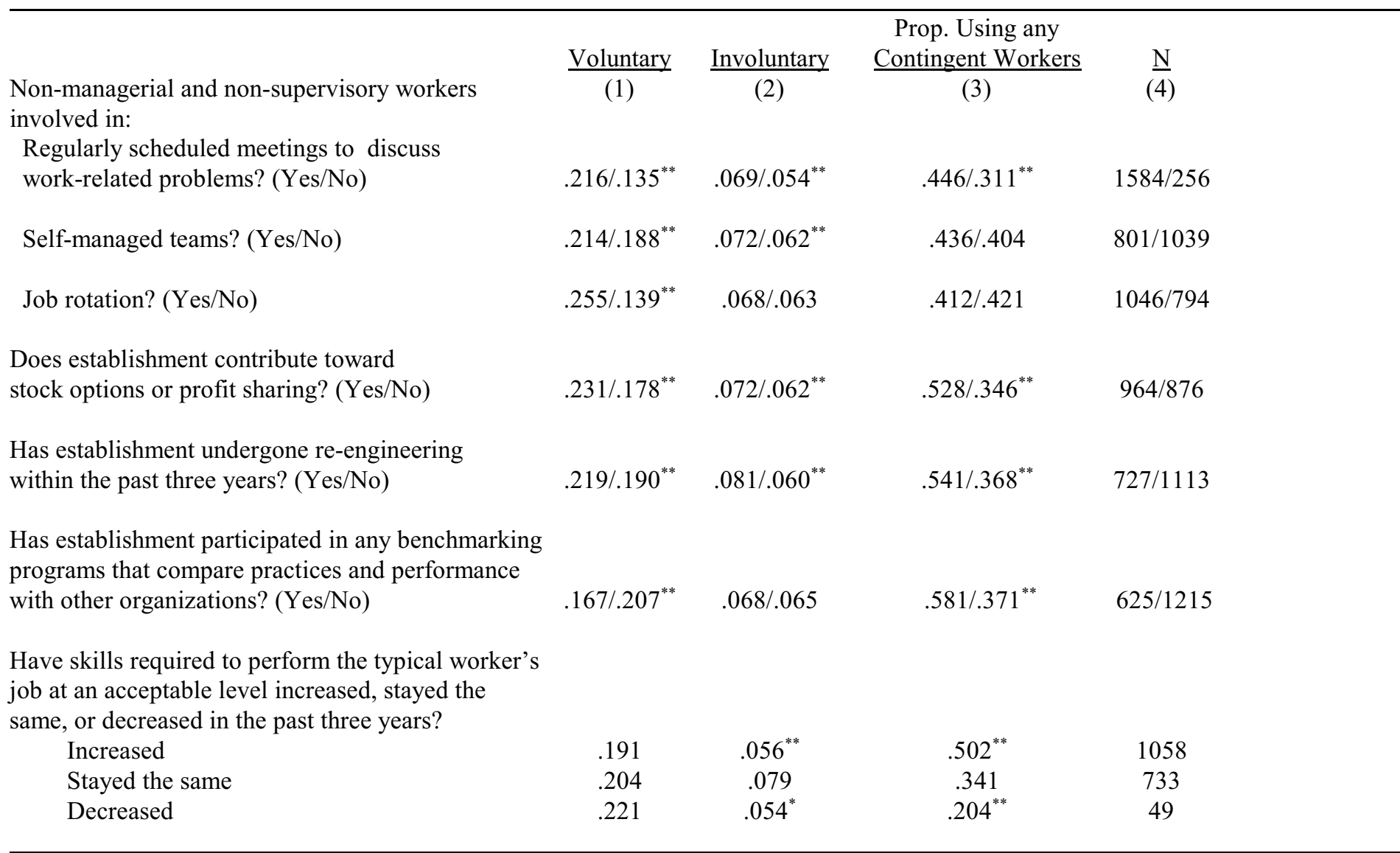

Estimates are sample weighted to be representative of establishments. In columns (1), (2), and (3), estimated differences significant at the fivepercent (ten-percent) level are indicated with ** $(*)$; for the skill change question, these are reported for differences relative to the "stayed the same" category. 
Table 3: Regression Estimates for Voluntary Turnover

\begin{tabular}{|c|c|c|c|c|c|c|c|}
\hline Meetings & $\begin{array}{l}(1) \\
.078^{* *} \\
(.015)\end{array}$ & $\begin{array}{l}(2) \\
.082^{* *} \\
(.015)\end{array}$ & $\begin{array}{l}(3) \\
.085^{* *} \\
(.015)\end{array}$ & $\begin{array}{l}(4) \\
.086^{* *} \\
(.014)\end{array}$ & $\begin{array}{c}\frac{\text { Employment }}{\text { weighted }} \\
(5) \\
.031^{* *} \\
(.014)\end{array}$ & $\begin{array}{c}\frac{\text { Non- }}{\text { Manufacturing }} \\
(6) \\
.093^{* *} \\
(.026)\end{array}$ & $\begin{array}{c}\text { Manufacturing } \\
(7) \\
.048^{* *} \\
(.013)\end{array}$ \\
\hline Self-managed teams & $\begin{array}{c}-.076^{* *} \\
(.020)\end{array}$ & $\begin{array}{c}-.071^{* *} \\
(.020)\end{array}$ & $\begin{array}{c}-.054^{* *} \\
(.020)\end{array}$ & $\begin{array}{c}.018 \\
(.019)\end{array}$ & $\begin{array}{c}.027 \\
(.021)\end{array}$ & $\begin{array}{l}.061^{*} \\
(.033)\end{array}$ & $\begin{array}{c}-.046^{* *} \\
(.018)\end{array}$ \\
\hline Job rotation & $\begin{array}{l}.139^{* *} \\
(.020)\end{array}$ & $\begin{array}{l}.140^{* *} \\
(.020)\end{array}$ & $\begin{array}{l}.118^{* *} \\
(.019)\end{array}$ & $\begin{array}{l}.066^{* *} \\
(.019)\end{array}$ & $\begin{array}{l}.110^{* *} \\
(.020)\end{array}$ & $\begin{array}{l}.102^{* *} \\
(.034)\end{array}$ & $\begin{array}{c}-.043^{* *} \\
(.017)\end{array}$ \\
\hline Profit sharing & $\begin{array}{l}.038^{* *} \\
(.013)\end{array}$ & $\begin{array}{l}.043^{* *} \\
(.013)\end{array}$ & $\begin{array}{l}.055^{* *} \\
(.013)\end{array}$ & $\begin{array}{c}.008 \\
(.013)\end{array}$ & $\begin{array}{l}.030^{* *} \\
(.013)\end{array}$ & $\begin{array}{l}.007 \\
(.023)\end{array}$ & $\begin{array}{c}-.029^{* *} \\
(.011)\end{array}$ \\
\hline Re-engineering & $\begin{array}{l}.026^{*} \\
(.014)\end{array}$ & $\begin{array}{l}.024^{*} \\
(.014)\end{array}$ & $\begin{array}{c}.018 \\
(.014)\end{array}$ & $\begin{array}{c}.010 \\
(.013)\end{array}$ & $\begin{array}{l}.013 \\
(.013)\end{array}$ & $\begin{array}{c}.007 \\
(.023)\end{array}$ & $\begin{array}{l}-.009 \\
(.013)\end{array}$ \\
\hline Benchmarking & $\begin{array}{c}-.042^{* *} \\
(.016)\end{array}$ & $\begin{array}{c}-.043^{* *} \\
(.016)\end{array}$ & $\begin{array}{l}-.016 \\
(.016)\end{array}$ & $\begin{array}{l}-.013 \\
(.015)\end{array}$ & $\begin{array}{c}.005 \\
(.013)\end{array}$ & $\begin{array}{c}.001 \\
(.027)\end{array}$ & $\begin{array}{c}.017 \\
(.013)\end{array}$ \\
\hline Skills increased & $\ldots$ & $\begin{array}{c}-.003 \\
(.014)\end{array}$ & $\begin{array}{c}.008 \\
(.013)\end{array}$ & $\begin{array}{c}.011 \\
(.012)\end{array}$ & $\begin{array}{l}-.017 \\
(.012)\end{array}$ & $\begin{array}{c}.024 \\
(.022)\end{array}$ & $\begin{array}{c}-.025^{* *} \\
(.012)\end{array}$ \\
\hline Skills decreased & $\ldots$ & $\begin{array}{l}.071^{* *} \\
(.030)\end{array}$ & $\begin{array}{c}.041 \\
(.029)\end{array}$ & $\begin{array}{c}.001 \\
(.027)\end{array}$ & $\begin{array}{c}-.005 \\
(.032)\end{array}$ & $\begin{array}{l}-.007 \\
(.045)\end{array}$ & $\begin{array}{c}.027 \\
(.034)\end{array}$ \\
\hline Weeks to fill opening & $\ldots$ & $\ldots$ & $\begin{array}{l}-.058^{* *} \\
(.013)\end{array}$ & $\begin{array}{l}.057^{* *} \\
(.014)\end{array}$ & $\begin{array}{l}.027^{*} \\
(.014)\end{array}$ & $\begin{array}{l}.078^{* *} \\
(.024)\end{array}$ & $\begin{array}{c}-.035^{* *} \\
(.012)\end{array}$ \\
\hline Candidates interviewed & $\ldots$ & $\ldots$ & $\begin{array}{l}-.025^{* *} \\
(.010)\end{array}$ & $\begin{array}{c}-.051^{* *} \\
(.009)\end{array}$ & $\begin{array}{c}-.035^{* *} \\
(.009)\end{array}$ & $\begin{array}{c}-.058^{* *} \\
(.016)\end{array}$ & $\begin{array}{l}-.008 \\
(.009)\end{array}$ \\
\hline Wage premium & $\ldots$ & $\ldots$ & $\begin{array}{l}-.157^{* *} \\
(.022)\end{array}$ & $\begin{array}{l}-.154^{* *} \\
(.021)\end{array}$ & $\begin{array}{c}-.183^{* *} \\
(.021)\end{array}$ & $\begin{array}{c}-.179^{* *} \\
(.037)\end{array}$ & $\begin{array}{c}-.079^{* *} \\
(.021)\end{array}$ \\
\hline Other controls & No & No & No & Yes & Yes & Yes & Yes \\
\hline
\end{tabular}

The dependent variable is the voluntary turnover rate. There are 1840 observations, 679 in non-manufacturing, and 1161 in manufacturing. Estimates are for one-tailed Tobits. For the work practice variables, the variables for meetings, self-managed teams, and job rotation are the proportions of workers involved, and the others are dummy variables. Other controls include: industry (21 two-digit industries); size (5 categories based on employment); multi-unit establishments; benefits (severance, pension, medical insurance, dental insurance, child care, family leave, life insurance, sick pay, vacation); occupation (percent managers/professionals, percent supervisors, percent technical, technical support, percent office, clerical, sales, customer service, and percent production); education (average education for managers and supervisors, and for other occupations, and an interaction of the latter with the percentage of workers in these occupations); months for typical new worker to become proficient; and age of equipment and machinery, as a proxy for plant age (percent of machinery and equipment less than 1 year old, 1-4 years old, 5-10 years old, and more than 10 years old). The wage premium is the residual from a regression of log average salary of permanent workers on the education, occupation, industry, and size variables, as well as the share of hours that are overtime. Estimates are sample weighted to be representative of establishments, except in column (5), where they are weighted to be representative of workers in the sampled population of establishments. The wage premium regression is always estimated using sample weights, to be representative of establishments. ${ }^{* *}\left({ }^{*}\right)$ indicates that the estimate was statistically significantly different from zero at the five-percent (ten-percent) level. 
Table 4: Regression Estimates for Involuntary Turnover

\begin{tabular}{|c|c|c|c|c|c|c|c|}
\hline Meetings & $\begin{array}{c}(1) \\
.005 \\
(.007)\end{array}$ & $\begin{array}{l}(2) \\
.010 \\
(.007)\end{array}$ & $\begin{array}{l}(3) \\
.011 \\
(.007)\end{array}$ & $\begin{array}{l}(4) \\
.010 \\
(.008)\end{array}$ & $\begin{array}{c}\frac{\text { Employment }}{\frac{\text { weighted }}{(5)}} \\
-.003 \\
(.007)\end{array}$ & $\begin{array}{c}\frac{\text { Non- }}{\text { Manufacturing }} \\
(6) \\
.007 \\
(.012)\end{array}$ & $\begin{array}{c}\text { Manufacturing } \\
(7) \\
.016 \\
(.011)\end{array}$ \\
\hline Self-managed teams & $\begin{array}{l}-.013 \\
(.010)\end{array}$ & $\begin{array}{l}-.010 \\
(.010)\end{array}$ & $\begin{array}{l}-.008 \\
(.010)\end{array}$ & $\begin{array}{l}-.006 \\
(.010)\end{array}$ & $\begin{array}{l}-.012 \\
(.011)\end{array}$ & $\begin{array}{l}.016 \\
(.016)\end{array}$ & $\begin{array}{c}-.063^{* *} \\
(.015)\end{array}$ \\
\hline Job rotation & $\begin{array}{l}.029^{* *} \\
(.009)\end{array}$ & $\begin{array}{l}.026^{* *} \\
(.009)\end{array}$ & $\begin{array}{l}.022^{* *} \\
(.009)\end{array}$ & $\begin{array}{c}.002 \\
(.010)\end{array}$ & $\begin{array}{l}-.001 \\
(.010)\end{array}$ & $\begin{array}{l}-.005 \\
(.016)\end{array}$ & $\begin{array}{l}-.006 \\
(.014)\end{array}$ \\
\hline Profit sharing & $\begin{array}{l}.012^{*} \\
(.006)\end{array}$ & $\begin{array}{l}.015^{* *} \\
(.006)\end{array}$ & $\begin{array}{l}.018^{* *} \\
(.006)\end{array}$ & $\begin{array}{l}.012^{*} \\
(.007)\end{array}$ & $\begin{array}{l}.015^{* *} \\
(.006)\end{array}$ & $\begin{array}{l}.027^{* *} \\
(.011)\end{array}$ & $\begin{array}{l}-.017^{*} \\
(.009)\end{array}$ \\
\hline Re-engineering & $\begin{array}{l}.022^{* *} \\
(.007)\end{array}$ & $\begin{array}{l}.025^{* *} \\
(.007)\end{array}$ & $\begin{array}{l}.026^{* *} \\
(.007)\end{array}$ & $\begin{array}{l}.029^{* *} \\
(.007)\end{array}$ & $\begin{array}{l}.022^{* *} \\
(.006)\end{array}$ & $\begin{array}{l}.025^{* *} \\
(.010)\end{array}$ & $\begin{array}{l}.031^{* *} \\
(.011)\end{array}$ \\
\hline Benchmarking & $\begin{array}{c}.009 \\
(.007)\end{array}$ & $\begin{array}{l}.018^{* *} \\
(.008)\end{array}$ & $\begin{array}{l}.021^{* *} \\
(.008)\end{array}$ & $\begin{array}{c}.007 \\
(.008)\end{array}$ & $\begin{array}{l}-.001 \\
(.007)\end{array}$ & $\begin{array}{l}.011 \\
(.012)\end{array}$ & $\begin{array}{l}-.008 \\
(.011)\end{array}$ \\
\hline Skills increased & $\ldots$ & $\begin{array}{c}-.034^{* *} \\
(.006)\end{array}$ & $\begin{array}{c}-.032^{* *} \\
(.007)\end{array}$ & $\begin{array}{c}-.031^{* *} \\
(.007)\end{array}$ & $\begin{array}{c}-.018^{* *} \\
(.006)\end{array}$ & $\begin{array}{c}-.042^{* *} \\
(.010)\end{array}$ & $\begin{array}{c}.006 \\
(.010)\end{array}$ \\
\hline Skills decreased & $\ldots$ & $\begin{array}{l}-.010 \\
(.014)\end{array}$ & $\begin{array}{l}-.012 \\
(.014)\end{array}$ & $\begin{array}{l}-.001 \\
(.015)\end{array}$ & $\begin{array}{l}-.005 \\
(.016)\end{array}$ & $\begin{array}{c}.008 \\
(.021)\end{array}$ & $\begin{array}{c}.005 \\
(.030)\end{array}$ \\
\hline Weeks to fill opening & $\ldots$ & $\ldots$ & $\begin{array}{c}-.019^{* *} \\
(.006)\end{array}$ & $\begin{array}{c}.008 \\
(.007)\end{array}$ & $\begin{array}{c}-.000 \\
(.007)\end{array}$ & $\begin{array}{c}.006 \\
(.011)\end{array}$ & $\begin{array}{c}-.002 \\
(.011)\end{array}$ \\
\hline Candidates interviewed & $\ldots$ & $\ldots$ & $\begin{array}{l}-.003 \\
(.005)\end{array}$ & $\begin{array}{l}-.008 \\
(.005)\end{array}$ & $\begin{array}{l}-.012^{* *} \\
(.005)\end{array}$ & $\begin{array}{l}-.006 \\
(.008)\end{array}$ & $\begin{array}{l}.001 \\
(.008)\end{array}$ \\
\hline Wage premium & $\ldots$ & $\ldots$ & $\begin{array}{c}-.009 \\
(.011)\end{array}$ & $\begin{array}{c}-.013 \\
(.011)\end{array}$ & $\begin{array}{c}-.029^{* *} \\
(.011)\end{array}$ & $\begin{array}{l}-.020 \\
(.017)\end{array}$ & $\begin{array}{l}-.035^{*} \\
(.018)\end{array}$ \\
\hline Other controls & No & No & No & Yes & Yes & Yes & Yes \\
\hline
\end{tabular}

The dependent variable is the involuntary turnover rate. Estimates are for one-tailed Tobits. See notes to Table 3. 
Table 5: Regression Estimates for Use of Contingent Workers

\begin{tabular}{|c|c|c|c|c|c|c|c|}
\hline Meetings & $\begin{array}{c}(1) \\
.006 \\
(.028)\end{array}$ & $\begin{array}{c}(2) \\
-.017 \\
(.029)\end{array}$ & $\begin{array}{c}(3) \\
-.017 \\
(.029)\end{array}$ & $\begin{array}{c}(4) \\
-.010 \\
(.034)\end{array}$ & $\begin{array}{c}\frac{\text { Employment }}{\text { weighted }} \\
(5) \\
-.007 \\
(.034)\end{array}$ & $\begin{array}{c}\frac{\text { Non- }}{\text { Manufacturing }} \\
(6) \\
-.007 \\
(.057)\end{array}$ & $\begin{array}{c}\text { Manufacturing } \\
(7) \\
.035 \\
(.043)\end{array}$ \\
\hline Self-managed teams & $\begin{array}{l}-.086^{* *} \\
(.038)\end{array}$ & $\begin{array}{c}-.107^{* *} \\
(.039)\end{array}$ & $\begin{array}{c}-.117^{* *} \\
(.039)\end{array}$ & $\begin{array}{l}-.043 \\
(.045)\end{array}$ & $\begin{array}{l}-.017 \\
(.048)\end{array}$ & $\begin{array}{l}-.098 \\
(.075)\end{array}$ & $\begin{array}{l}.160^{* *} \\
(.060)\end{array}$ \\
\hline Job rotation & $\begin{array}{l}-.022 \\
(.037)\end{array}$ & $\begin{array}{l}-.015 \\
(.037)\end{array}$ & $\begin{array}{l}-.018 \\
(.038)\end{array}$ & $\begin{array}{l}-.020 \\
(.043)\end{array}$ & $\begin{array}{l}-.049 \\
(.046)\end{array}$ & $\begin{array}{l}.001 \\
(.074)\end{array}$ & $\begin{array}{l}-.078 \\
(.054)\end{array}$ \\
\hline Profit sharing & $\begin{array}{l}.153^{* *} \\
(.024)\end{array}$ & $\begin{array}{l}.132^{* *} \\
(.025)\end{array}$ & $\begin{array}{l}.111^{* *} \\
(.025)\end{array}$ & $\begin{array}{l}.092^{* *} \\
(.030)\end{array}$ & $\begin{array}{l}.059^{* *} \\
(.030)\end{array}$ & $\begin{array}{l}.118^{* *} \\
(.053)\end{array}$ & $\begin{array}{l}-.009 \\
(.034)\end{array}$ \\
\hline Re-engineering & $\begin{array}{l}.126^{* *} \\
(.027)\end{array}$ & $\begin{array}{l}.123^{* *} \\
(.027)\end{array}$ & $\begin{array}{l}.111^{* *} \\
(.028)\end{array}$ & $\begin{array}{l}.083^{* *} \\
(.031)\end{array}$ & $\begin{array}{l}.088^{* *} \\
(.029)\end{array}$ & $\begin{array}{l}.119^{* *} \\
(.051)\end{array}$ & $\begin{array}{l}-.051 \\
(.041)\end{array}$ \\
\hline Benchmarking & $\begin{array}{l}.166^{* *} \\
(.029)\end{array}$ & $\begin{array}{l}.148^{* *} \\
(.030)\end{array}$ & $\begin{array}{l}.153^{* *} \\
(.031)\end{array}$ & $\begin{array}{l}.095^{* *} \\
(.035)\end{array}$ & $\begin{array}{c}.042 \\
(.031)\end{array}$ & $\begin{array}{l}.119^{* *} \\
(.062)\end{array}$ & $\begin{array}{c}.043 \\
(.043)\end{array}$ \\
\hline Skills increased & $\ldots$ & $\begin{array}{l}.108^{* *} \\
(.025)\end{array}$ & $\begin{array}{l}.092^{* *} \\
(.026)\end{array}$ & $\begin{array}{l}.094^{* *} \\
(.028)\end{array}$ & $\begin{array}{c}.027 \\
(.029)\end{array}$ & $\begin{array}{l}.096^{* *} \\
(.047)\end{array}$ & $\begin{array}{c}.060 \\
(.037)\end{array}$ \\
\hline Skills decreased & $\ldots$ & $\begin{array}{c}-.179^{* *} \\
(.051)\end{array}$ & $\begin{array}{c}-.202^{* *} \\
(.049)\end{array}$ & $\begin{array}{l}-.068 \\
(.068)\end{array}$ & $\begin{array}{l}-.080 \\
(.080)\end{array}$ & $\begin{array}{l}-.071 \\
(.101)\end{array}$ & $\begin{array}{l}-.044 \\
(.114)\end{array}$ \\
\hline Weeks to fill opening & $\ldots$ & $\ldots$ & $\begin{array}{l}.211^{* *} \\
(.025)\end{array}$ & $\begin{array}{l}.108^{* *} \\
(.031)\end{array}$ & $\begin{array}{l}.120^{* *} \\
(.034)\end{array}$ & $\begin{array}{l}.126^{* *} \\
(.051)\end{array}$ & $\begin{array}{c}.076^{*} \\
(.042)\end{array}$ \\
\hline Candidates interviewed & $\ldots$ & $\ldots$ & $\begin{array}{c}-.081^{* *} \\
(.020)\end{array}$ & $\begin{array}{c}-.045^{* *} \\
(.021)\end{array}$ & $\begin{array}{l}-.037^{*} \\
(.021)\end{array}$ & $\begin{array}{l}-.044 \\
(.035)\end{array}$ & $\begin{array}{l}-.026 \\
(.030)\end{array}$ \\
\hline Wage premium & $\ldots$ & $\ldots$ & $\begin{array}{l}-.180^{* *} \\
(.043)\end{array}$ & $\begin{array}{l}-.120^{* *} \\
(.050)\end{array}$ & $\begin{array}{l}-.117^{* *} \\
(.049)\end{array}$ & $\begin{array}{l}-.101 \\
(.085)\end{array}$ & $\begin{array}{c}-.163^{* *} \\
(.068)\end{array}$ \\
\hline Other controls & No & No & No & Yes & Yes & Yes & Yes \\
\hline
\end{tabular}

The dependent variable is a dummy variable for whether contingent workers are used. Estimates are for probits, with derivatives of probability of outcome reported, and standard errors adjusted to replicate t-statistics of probit coefficient estimates. See notes to Table 3. 
Table 6: Regression Estimates for Involuntary Turnover and Use of Contingent Workers

\begin{tabular}{|c|c|c|c|c|c|c|}
\hline & (1) & (2) & (3) & $\frac{\text { Employment }}{\frac{\text { weighted }}{(4)}}$ & $\frac{\frac{\text { Non- }}{\text { Manufacturing }}}{(5)}$ & $\frac{\text { Manufacturing }}{(6)}$ \\
\hline Uses contingent workers & $\begin{array}{l}.019^{* *} \\
(.006)\end{array}$ & $\begin{array}{l}.024^{* *} \\
(.006)\end{array}$ & $\begin{array}{l}.033^{* *} \\
(.007)\end{array}$ & $\begin{array}{l}.027^{* *} \\
(.007)\end{array}$ & $\begin{array}{l}.037^{* *} \\
(.010)\end{array}$ & $\begin{array}{l}.022^{* *} \\
(.010)\end{array}$ \\
\hline Weeks to fill opening & $\ldots$ & $\begin{array}{l}-.023^{* *} \\
(.007)\end{array}$ & $\begin{array}{l}.007 \\
(.008)\end{array}$ & $\begin{array}{l}-.001 \\
(.007)\end{array}$ & $\begin{array}{l}.008 \\
(.012)\end{array}$ & $\begin{array}{l}-.003 \\
(.011)\end{array}$ \\
\hline Candidates interviewed & $\ldots$ & $\begin{array}{l}.000 \\
(.005)\end{array}$ & $\begin{array}{l}-.005 \\
(.005)\end{array}$ & $\begin{array}{l}-.011^{* *} \\
(.005)\end{array}$ & $\begin{array}{l}-.001 \\
(.007)\end{array}$ & $\begin{array}{l}.005 \\
(.008)\end{array}$ \\
\hline Wage premium & $\ldots$ & $\begin{array}{l}-.011 \\
(.010)\end{array}$ & $\begin{array}{l}-.016 \\
(.011)\end{array}$ & $\begin{array}{l}-.030^{* *} \\
(.010)\end{array}$ & $\begin{array}{l}-.025 \\
(.017)\end{array}$ & $\begin{array}{l}-.028 \\
(.019)\end{array}$ \\
\hline Other controls & No & No & Yes & Yes & Yes & Yes \\
\hline
\end{tabular}

The dependent variable is the involuntary turnover rate. Estimates are for one-tailed Tobits. See notes to Table 3. 